\title{
THE PATTERN OF RESPIRATION IN RHEUMATIC HEART DISEASE
}

\author{
BY \\ R. J. SHEPHARD AND ALBERT VENNER \\ From the Cardiac Department, Guy's Hospital
}

Received June 14, 1955

It is well known that the earliest symptom of mitral stenosis is shortness of breath with moderate exertion (Baker, Brock, Campbell, and Wood, 1952). However, the relationship between this sensation of dyspnœa and departures from the normal pattern of respiratory function is less clearly defined.

It has been shown recently (Shephard, 1955a) that in congenital heart cases there is a relationship that is highly significant statistically between the level of pulmonary flow and the depth of respiration. This finding was explained by postulating an associated alteration in the elastic properties of the lungs. With an increase of pulmonary blood flow it was suggested there was an increased resistance to distension, leading to the adoption of a shallow and inefficient pattern of respiration. There is some evidence that a similar change occurs with the pulmonary congestion of mitral stenosis and other forms of rheumatic heart disease. It was shown many years ago (Campbell, Hunt, and Poulton, 1923; Campbell and Sale, 1927) that patients with mitral stenosis tended to develop a rapid, shallow pattern of respiration, and calculations of the work of breathing (Christie and Meakins, 1934; Christie, 1953) have given support to this concept of respiratory inefficiency.

The present paper reports our findings in a group of 116 patients with rheumatic heart disease (55 with pure mitral stenosis, and 61 with other valvular lesions). The pattern of respiration before and during moderate exercise is examined, and compared with the degree of disability (based on history, see Baker et al., 1952) and hæmodynamic measurements made at cardiac catheterization. The problem of dyspnœa is discussed, and an analysis made of the factors contributing to this symptom in rheumatic heart disease.

\section{METHODS}

The Patients. Cases were unselected patients presented for cardiac catheterization but a small number were omitted from the analysis owing to lack of co-operation, or a disturbed emotional state (as shown by a high metabolic rate). A light breakfast was given three hours before the tests, and at a suitable interval phenobarbitone ( $1 \frac{1}{2}-2$ grains) or amytobarbitone ( 3 grains). On this regime, most patients seemed close to a basal state, the average metabolic rate for the group being +5.9 per cent. The age, sex distribution, and degree of disability of the cases are summarized in Table I, and for purposes of analysis, the patients have been divided into eight groups.

Technique of Catheterization. The basic technique has been reported by Holling and Zak (1950). Simultaneous pulmonary arterial and capillary tracings are now obtained via a Cournand double-lumen catheter. Pressures are recorded by a twin-channel Southern Instruments capacitance manometer, and Brush direct-writing galvanometers. The oxygen content of blood samples has been determined by the Haldane technique, and more recently by a Beckmann spectrophotometer (Nahas, 1950; Holling et al., 1955).

Respiratory measurements were made by the box-bag technique (Donald and Christie, 1949), the patient lying on a couch with the back supported at an angle of 45 degrees. This angulation was adopted as a routine as a number of the patients showed orthopnoa. A number of control observations were made on students under the same experimental conditions. Vital capacity and supplemental air measurements 
TABLE I

Age, SeX, and Disability of Cases

\begin{tabular}{|c|c|c|c|c|c|c|c|c|}
\hline & \multicolumn{4}{|c|}{ Mitral stenosis alone } & \multicolumn{4}{|c|}{$\begin{array}{l}\text { All other rheumatic valve lesions with or } \\
\text { without mitral stenosis }\end{array}$} \\
\hline & \multicolumn{2}{|c|}{ Normal rhythm } & \multicolumn{2}{|c|}{ Fibrillating } & \multicolumn{2}{|c|}{ Normal rhythm } & \multicolumn{2}{|c|}{ Fibrillating } \\
\hline & Men & Women & Men & Women & Men & Women & Men & Women \\
\hline Number of cases & 10 & 30 & 10 & 5 & 4 & 15 & 11 & 31 \\
\hline Average age of group & $34 \cdot 6$ & $33 \cdot 7$ & $37 \cdot 6$ & $38 \cdot 0$ & $38 \cdot 3$ & $35 \cdot 7$ & $42 \cdot 1$ & $38 \cdot 5$ \\
\hline $\begin{array}{l}\text { Disability with } \\
\text { standard error }\end{array}$ & $\begin{array}{r}3 \cdot 0 \\
\pm 0 \cdot 3\end{array}$ & $\begin{array}{r}2 \cdot 5 \\
\pm 0 \cdot 2\end{array}$ & $\begin{array}{r}2.9 \\
\pm 0.2\end{array}$ & $\begin{array}{r}2 \cdot 3 \\
\pm 0.5\end{array}$ & $\begin{array}{r}3 \cdot 5 \\
\pm 0 \cdot 3\end{array}$ & $\begin{array}{r}2 \cdot 7 \\
\pm 0 \cdot 3\end{array}$ & $\begin{array}{r}3 \cdot 1 \\
\pm 0 \cdot 1\end{array}$ & $\begin{array}{r}3 \cdot 4 \\
\pm 0 \cdot 2\end{array}$ \\
\hline
\end{tabular}

represent the best of three successive estimations. Exercise was provided by a standard pedalling test (described elsewhere: Holling and Venner, 1955), and respiratory measurements were repeated during the fourth minute of this test.

Measures of Disability. The available measures of cardiac dysfunction comprise the clinical grading and hæmodynamic measurements - the pulmonary arterial and pulmonary capillary pressures and the pulmonary flow. Before attempting to correlate respiratory changes with these values, the practical limitations of each must be considered.

The clinical grading is often used for the construction of graphs-sometimes even the logarithm of the clinical grading is pressed into service. However, it is unlikely that a series of clinical grades will bear any close relation to a normal numerical sequence, and mathematical manipulations with such gradings should therefore be used with caution.

The pulmonary arterial pressure has a definite numerical value, but there is a possibility that the higher pressures sometimes serve a protective function (Lewis et al., 1952) and are not related simply to " backpressure " effects from stenosis at the mitral valve.

Since an increased capillary blood content and an interstitial œdema are generally considered responsible for the rigidity of the lungs in chronic heart disease, the pulmonary capillary pressure might seem the ideal figure to relate to respiratory changes. In practice, it is difficult to measure, and even when satisfactory tracings are obtained by the wedge technique, the pressure recorded bears no certain relationship to the true capillary pressure. Finally, with increase of disability, pulmonary capillary pressure soon reaches a limiting value (Lewis et al., 1952). The resting pulmonary blood flow is not much reduced in rheumatic heart disease, and bears little relationship to the clinical disability (Holling and Venner, 1956).

The above difficulties are not sufficient to prevent the successful use of hæmodynamic measurements in clinical assessment (Holling and Venner, 1956), but they do limit the possibility of establishing clear correlations between these measurements and changes in the pattern of respiration.

\section{The Pattern of Resting Respiration}

Respiratory Minute Volume. The usually accepted minute volume for adult subjects is $4.01 . /$ sq.m./ min. B.T.P.S. (Shephard, 1954), and the value of $4 \cdot 12 \pm 0 \cdot 301 . / \mathrm{sq} . \mathrm{m} . / \mathrm{min}$. found for six control subjects corresponds closely with this standard. The patients with rheumatic heart disease all show a minute volume slightly greater than normal (Table II). An increase of this order could be due to greater anxiety on the part of the patients, but recent figures published by Wade et al. (1953) show a similar trend, with a tendency to decrease of ventilatory volume following valvotomy. The increase of ventilation does not show any correlation with clinical disability or the pulmonary vascular measurements discussed above.

Respiratory Rate. The average respiratory rate (Table II) is very little above the value of $15 \cdot 3$ \pm 0.9 found for the normal control subjects. This would seem to imply that in this group of patients, the elastic work of resting respiration is not greatly different from normal, since with increased elastic work a higher frequency of respiration is adopted (Fenn, 1951; Christie, 1953). 
TABLE II

Pattern of Resting Respiration in Rheumatic Heart Disease with the Mean and Standard ErRor for EACH GROUP OF DATA

\begin{tabular}{|c|c|c|c|c|c|c|c|c|c|}
\hline & \multicolumn{4}{|c|}{ Pure mitral stenosis } & \multicolumn{4}{|c|}{ Other rheumatic valve lesions } & \multirow{2}{*}{$\begin{array}{l}\text { Average for } \\
8 \text { groups }\end{array}$} \\
\hline & \multicolumn{2}{|c|}{ Normal rhythm } & \multicolumn{2}{|c|}{ Fibrillating } & \multicolumn{2}{|c|}{ Normal rhythm } & \multicolumn{2}{|c|}{ Fibrillating } & \\
\hline & Men & Women & Men & Women & Men & Women & Men & Women & \\
\hline $\begin{array}{l}\text { Minute volume } \\
1 . / \mathrm{m} .2 / \mathrm{min} . \text { (BTPS) }\end{array}$ & $\begin{array}{r}4 \cdot 5 \\
\pm 0 \cdot 3\end{array}$ & $\begin{array}{r}4 \cdot 5 \\
\pm 0 \cdot 2\end{array}$ & $\begin{array}{r}4 \cdot 6 \\
\pm 0.5\end{array}$ & $\begin{array}{r}5 \cdot 2 \\
\pm 0 \cdot 4\end{array}$ & $\begin{array}{r}5.0 \\
\pm 0.2\end{array}$ & $\begin{array}{r}4 \cdot 4 \\
\pm 0 \cdot 4\end{array}$ & $\begin{array}{r}5 \cdot 0 \\
\pm 0 \cdot 3\end{array}$ & $\begin{array}{r}4 \cdot 5 \\
\pm 0 \cdot 2\end{array}$ & $\begin{array}{r}4 \cdot 59 \\
\pm 0 \cdot 11\end{array}$ \\
\hline Respiratory rate/min. & $\begin{array}{r}14 \cdot 8 \\
\pm 1.8\end{array}$ & $\begin{array}{r}16 \cdot 5 \\
\pm 0 \cdot 6\end{array}$ & $\begin{array}{r}14 \cdot 2 \\
\pm 1 \cdot 4\end{array}$ & $\begin{array}{r}17 \cdot 2 \\
\pm 1 \cdot 0\end{array}$ & $\begin{array}{r}15 \cdot 8 \\
\pm 1 \cdot 0\end{array}$ & $\begin{array}{r}17 \cdot 1 \\
\pm 1 \cdot 2\end{array}$ & $\begin{array}{r}16 \cdot 7 \\
\pm 1 \cdot 7\end{array}$ & $\begin{array}{r}16.5 \\
\pm 1.0\end{array}$ & $\begin{array}{r}16 \cdot 3 \\
\pm 0.5\end{array}$ \\
\hline $\begin{array}{l}\text { Tidal volume } \\
\mathrm{ml} . / \mathrm{m} .{ }^{2} \text { (BTPS) }\end{array}$ & $\begin{array}{r}324 \\
\pm 32\end{array}$ & $\begin{array}{r}281 \\
\pm 16\end{array}$ & $\begin{array}{r}318 \\
\pm 18\end{array}$ & $\begin{array}{r}307 \\
\pm 28\end{array}$ & $\begin{array}{r}323 \\
\pm 18\end{array}$ & $\begin{array}{r}264 \\
\pm 20\end{array}$ & $\begin{array}{r}334 \\
\pm 38\end{array}$ & $\begin{array}{r}288 \\
\pm 12\end{array}$ & $\mid \begin{array}{cl}325(\mathrm{M}) & 282(\mathrm{~F}) \\
\pm 15 & \pm 9\end{array}$ \\
\hline $\begin{array}{l}\text { Vital capacity } \\
\text { (ml. ATPS) }\end{array}$ & 2587 & $\begin{array}{r}2367 \\
\pm 123\end{array}$ & $\begin{array}{r}2723 \\
\pm 220\end{array}$ & 2550 & 3013 & $\begin{array}{r}2071 \\
\pm 105\end{array}$ & 2275 & $\begin{array}{l}1942 \\
\pm 86\end{array}$ & $\begin{array}{l}2345 \\
\pm 76\end{array}$ \\
\hline $\begin{array}{l}\text { Tidal volume (percen- } \\
\text { tage of vital capacity) }\end{array}$ & $20 \cdot 9$ & $\begin{array}{r}21 \cdot 5 \\
\pm 2 \cdot 2\end{array}$ & $\begin{array}{r}21 \cdot 5 \\
\pm 2 \cdot 8\end{array}$ & $21 \cdot 8$ & $18 \cdot 0$ & $\begin{array}{r}18 \cdot 3 \\
\pm 1 \cdot 8\end{array}$ & $21 \cdot 5$ & $\begin{array}{r}23 \cdot 0 \\
\pm 1.7\end{array}$ & $\begin{array}{l}21 \cdot 2 \\
\pm 0 \cdot 9\end{array}$ \\
\hline $\begin{array}{l}\text { Expiratory reserve } \\
\text { (percentage of vital } \\
\text { capacity) }\end{array}$ & $19 \cdot 8$ & $\begin{array}{r}20 \cdot 0 \\
\pm 1 \cdot 5\end{array}$ & $\begin{array}{r}22 \cdot 3 \\
\pm 2 \cdot 5\end{array}$ & $30 \cdot 9$ & $31 \cdot 6$ & $\begin{array}{r}25 \cdot 1 \\
\pm 1 \cdot 8\end{array}$ & $17 \cdot 7$ & $\begin{array}{r}23 \cdot 7 \\
\pm 2 \cdot 1\end{array}$ & $\begin{array}{r}23 \cdot 2 \\
\pm 1 \cdot 1\end{array}$ \\
\hline
\end{tabular}

Tidal Volume. There is a significant difference between the sexes with respect to tidal volume (Table II), and it is therefore necessary to compare with controls of the same sex. Such a comparison shows that in the women patients (the larger group), the tidal volume per square metre of body surface is significantly greater than normal $(P<0.0001)$. No correlation can be shown between this increase of tidal volume and the clinical or hæmodynamic measures of disability; this may be explained by the fact that while the central effects of rheumatic heart disease tend to increase tidal volume by their action on the respiratory centre, this tendency is opposed by the increased rigidity of the lungs.

Vital Capacity. The vital capacity is considerably reduced in all groups (Table II), the corresponding values for normal controls being $4420 \mathrm{ml}$. (men) and $3345 \pm 220 \mathrm{ml}$. (women). In their classical study of 156 " cardiac" cases, Peabody and Wentworth (1917) reported a reduced vital capacity in patients with dyspnœa, and suggested that the lowest values were obtained in patients with decompensation. Some subsequent workers have supported this view (Richards et al, 1951; Halmagyi, 1954). On the other hand Holling and Venner (1956) have suggested that the alterations of vital capacity that can be found in rheumatic heart disease are related more to restricted lives and poor physique than to cardiac status. The present series certainly shows little correlation between clinical grade and vital capacity $(P=0 \cdot 3)$. However, it may be significant that all of the 7 cases with a vital capacity of less than $1250 \mathrm{ml}$./sq.m. have a disability grading of 3 or 4 . It is also interesting to note that of the women patients, there is a clear difference $(P<0.001)$ between the pure mitral stenosis cases (average disability 2.49 ) and those with added valvular lesions (average disability 3.04).

The vital capacity does not show any correlation with the hæmodynamic measures of disability. This is probably explained once again by the fact that changes of vital capacity are determined largely by secondary factors (physique, œdema, infarcts, changes of cardiac size and pulmonary blood volume); these are dependent more on the behaviour of the patient than on the actual size of the mitral orifice.

Calculating the tidal volume as a percentage of the vital capacity, it can be seen that in most 
instances the resting ventilation is over 20 per cent of the vital capacity, as compared with the normal control value of some 12 per cent. It is suggested that a ventilation of some $35-40$ per cent of the vital capacity is sufficient to produce the symptoms of dyspnoa (Cournand and Richards, 1941), and if this is so it requires a much smaller relative change of tidal volume to produce dyspnœa in these patients.

Chest Position. The expiratory reserve volume is a little below the value of 26.8 per cent of the vital capacity found in the control cases, this difference being on the border line of statistical significance $(P=0.05-0 \cdot 10)$. Bearing in mind that the vital capacity is also reduced in rheumatic heart disease, the absolute decrease of expiratory reserve is somewhat larger $(350-500 \mathrm{ml}$.). This change may be due mainly to the increase of residual air that has been noted in pulmonary congestion (Drinker et al., 1922; Mack et al., 1947), but it is possible that an increased viscosity of the lung tissues also has a direct effect on end-tidal position, the lung showing a smaller average distension at the end of a normal expiration.

\section{The Response to EXERCISE}

The amount of exercise performed can be gauged approximately from the change of oxygen consumption. In our normal subjects this averaged 113 per cent of the resting metabolic rate, and it was associated with an increase of 24 per cent in respiratory rate, and 42 per cent in tidal volume giving a 73 per cent increase of minute volume (Fig. 1).

Respiratory Minute Volume. The rheumatic heart cases co-operated less well during the exercise test, and the change of metabolism was only 83 per cent. of the resting level. Despite this, the change of respiratory minute volume tends to be greater than in normal subjects (Table III).

TABLE III

Change of Respiratory Pattern with Exercise with the Mean and Standard Error for Each Group OF PATIENTS

\begin{tabular}{|c|c|c|c|c|c|c|c|c|c|}
\hline & \multicolumn{4}{|c|}{ Pure mitral stenosis } & \multicolumn{4}{|c|}{ Other rheumatic valve lesions } & \multirow{3}{*}{$\begin{array}{l}\text { Average for } \\
8 \text { groups }\end{array}$} \\
\hline & \multicolumn{2}{|c|}{ Normal rhythm } & \multicolumn{2}{|c|}{ Fibrillating } & \multicolumn{2}{|c|}{ Normal rhythm } & \multicolumn{2}{|c|}{ Fibrillating } & \\
\hline & Men & Women & Men & Women & Men & Women & Men & Women & \\
\hline $\begin{array}{l}\text { Change of minute } \\
\text { volume* }\end{array}$ & $\begin{array}{r}82 \cdot 8 \\
\pm 12 \cdot 6\end{array}$ & 83.9 & $\begin{array}{r}67 \cdot 5 \\
\pm 9 \cdot 1\end{array}$ & $73 \cdot 7$ & $\begin{array}{r}67 \cdot 5 \\
\pm 16 \cdot 4\end{array}$ & $\begin{array}{r}119 \cdot 3 \\
\pm 10 \cdot 5\end{array}$ & $\begin{array}{r}91 \cdot 8 \\
\pm 27 \cdot 7\end{array}$ & $\begin{array}{r}71 \cdot 4 \\
\pm 5 \cdot 6\end{array}$ & $\begin{array}{r}81 \cdot 9 \\
\pm 4 \cdot 9\end{array}$ \\
\hline $\begin{array}{l}\text { Change of respiratory } \\
\text { rate* }^{*}\end{array}$ & $\begin{array}{r}34 \cdot 0 \\
\pm 12 \cdot 9\end{array}$ & $\begin{array}{r}38 \cdot 2 \\
\pm 8 \cdot 4\end{array}$ & $\begin{array}{r}14 \cdot 3 \\
\pm 6 \cdot 6\end{array}$ & $50 \cdot 0$ & $35 \cdot 8$ & $\begin{array}{r}53 \cdot 1 \\
\pm 10 \cdot 0\end{array}$ & $48 \cdot 8$ & $\begin{array}{r}41 \cdot 7 \\
7 \pm \cdot 0\end{array}$ & $\begin{array}{r}39 \cdot 3 \\
\pm 3 \cdot 8\end{array}$ \\
\hline $\begin{array}{l}\text { Change of tidal } \\
\text { volume* }\end{array}$ & $\begin{array}{r}33 \cdot 5 \\
\pm 9 \cdot 0\end{array}$ & $\begin{array}{r}33 \cdot 3 \\
\pm 7 \cdot 5\end{array}$ & $\begin{array}{r}49 \cdot 5 \\
\pm 12 \cdot 6\end{array}$ & $15 \cdot 7$ & $\begin{array}{r}27 \cdot 0 \\
\pm 13 \cdot 4\end{array}$ & $\begin{array}{r}44 \cdot 1 \\
\pm 10 \cdot 1\end{array}$ & $31 \cdot 2$ & $\begin{array}{r}24 \cdot 6 \\
\pm 4 \cdot 9\end{array}$ & $\begin{array}{r}32 \cdot 8 \\
\pm 3 \cdot 4\end{array}$ \\
\hline
\end{tabular}

* All these are expressed as percentages of the normal level.

There is a considerable loss of respiratory efficiency in the rheumatic heart cases, and this may be examined simply in terms of the "ventilatory equivalent" for oxygen. In the controls, there is a resting ventilation of $2.841 . / 100 \mathrm{ml}$. of oxygen consumption, and with exercise this "ventilatory equivalent" falls to $2 \cdot 30$. On the other hand the rheumatic patients show little change with exercise, the corresponding "ventilatory equivalent" values being $3 \cdot 17$ and $3 \cdot 131 . / 100 \mathrm{ml}$. oxygen.

Respiratory Rate and Tidal Volume. The most interesting feature of the response to exercise is the manner of achieving the increase of minute volume (Fig. 1). The change of rate is almost double that observed in normal subjects, while the increase of tidal volume is not greatly different from normal. This is almost certainly a manifestation of the altered elastic properties of the lungs, and it serves to emphasize the point that even where the pattern of resting respiration is normal, moderate exercise may produce sufficient pulmonary congestion to initiate a rapid and inefficient form of ventilation. 


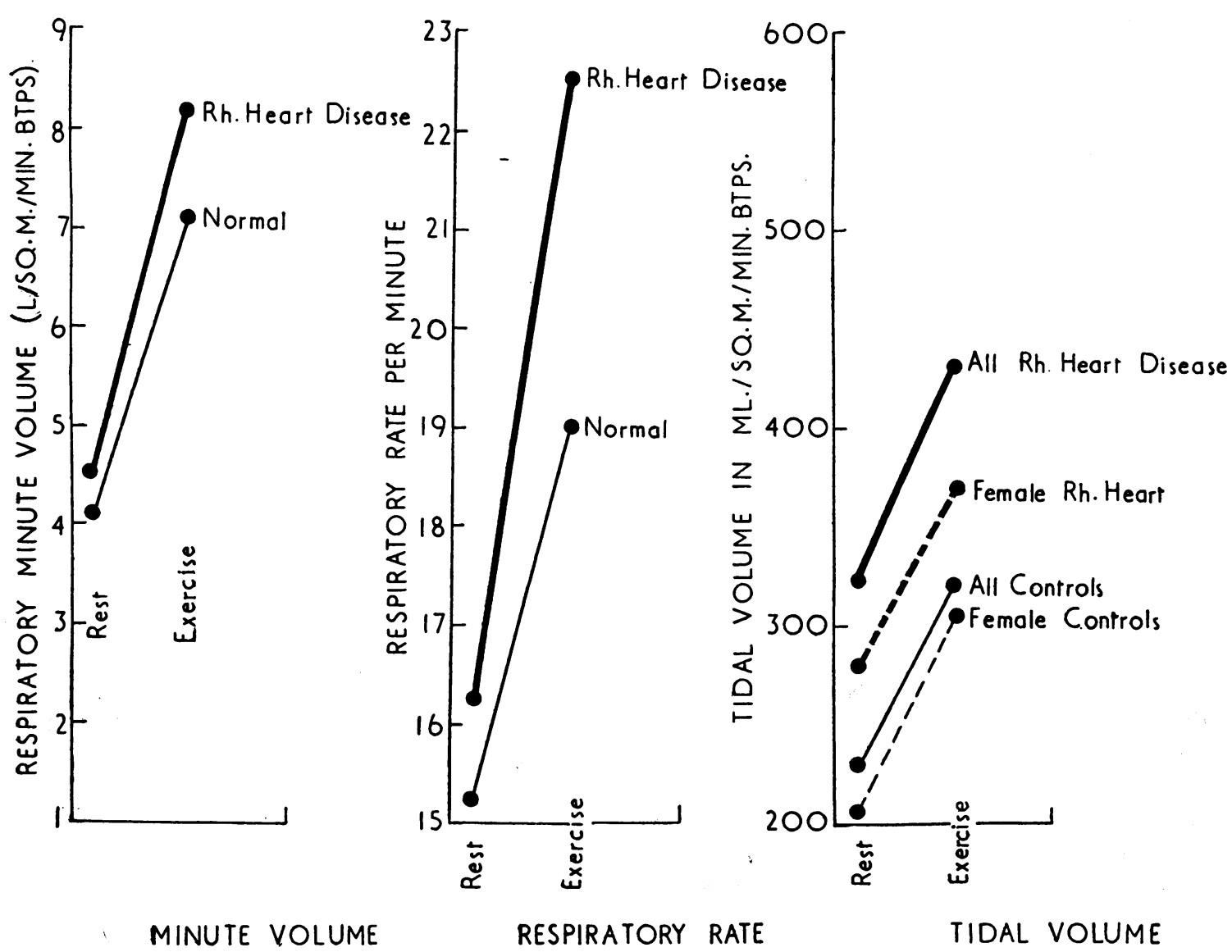

FIG. 1.-The effect of a standard exercise test (Holling and Venner, 1955) on the respiration of normal subjects and a group of 116 cases of rheumatic heart disease. The minute volume is shown on the left, the respiratory rate in the centre, and the tidal volume on the right.

Although the pattern of response to exercise shows a striking departure from normality, it is not possible to establish a correlation between the respiratory rate during exercise and clinical disability or pulmonary vascular measurements. In the case of pulmonary arterial pressure, the explanation may be that the rise of pressure is " protective" in type, and actually limits the change in the pattern of respiration. Again, during exercise, almost all patients are close to the limiting pulmonary capillary pressure of $30 \mathrm{~mm}$. $\mathrm{Hg}$, and a clear correlation of capillary pressure with respiratory changes would not therefore be anticipated. However, the lack of relationship between clinical grading and the respiratory rate during exercise cannot be attributed to extraneous factors. and it implies that an increase of respiratory rate plays little part in the production of dyspnœa.

\section{Discussion}

Two factors appear to affect the elasticity of the lungs in rheumatic heart disease-an increase of tissue fluid ("lungenschwellung") and an increase of pulmonary blood volume ("lungenstarre" effect: Basch 1891). The total capacity of the chest may also be reduced by a variety of factors, including poor physique, an increased pulmonary blood volume, increased heart size, œdema, effusions, and infarcts. Our findings show that at rest the resultant pattern of respiration in the average case of rheumatic heart disease is very close to normal, but that moderate exercise usually 
reveals the rapid and shallow pattern of respiration that has been thought typical of mitral stenosis (Campbell et al., 1923; Christie, 1953).

The rather rapid nature of respiration during exercise seems to play a comparatively minor part in the development of dyspnœa. A more important feature is apparently the reduction in vital capacity. Even if the patient is allowed to take his time over the expiration, his capacity is much reduced, and it is probable that during rapid respiration the effective capacity is still smaller owing to the "lungenstarre" effect. The ventilatory efficiency is also reduced and, as a result of these two factors, a comparatively mild amount of exercise is sufficient to reach the dyspnœa threshold. Laboratory evaluation of dyspnœa should therefore be in terms of fast vital capacity and ventilatory efficiency, perhaps in the manner suggested by Stocks and Kennedy (1953), although the E.F.R. ${ }^{40}$ value in their equation should preferably be replaced by pooled fast inspiratory and expiratory vital capacity data (Shephard, 1955b).

It must be remembered that central carbon dioxide accumulation, psychological influences, and reflex sequelæ of pulmonary congestion may all play some part in reaching the dyspnœa threshold, and these are not assessed by tests of breathing capacity. The general circulation time is increased in mitral stenosis, particularly when the heart is enlarged (Tarr et al., 1933; Cannon et al., 1939; Gübner et al., 1939). Assuming this slowing of the circulation to extend to the cerebral circulation, an abnormal local accumulation of carbon dioxide in the tissues of the respiratory centre might be anticipated, and the relatively normal arterial carbon dioxide content (Campbell et al., 1923) despite recurrent hyperpnœa is in keeping with a situation of this type. Again, many patients have been conditioned to regard themselves as invalids, particularly during childhood and adolescence, and this, together with lack of physical training undoubtedly contributes to the lowered dyspnœa threshold. Finally, pulmonary congestion may exert some action via pulmonary pressure receptors (Bülbring and Whitteridge, 1945).

It seems unlikely that formal laboratory respiratory tests will replace cardiac catheterization in the assessment of rheumatic heart disease, but in the measurement of dyspnœa they should form a useful ancillary to the usual clinical grading. Possibly, simple measurements of respiratory rate or more complicated measurements of the work of breathing may also help increasingly in evaluating the onset of pulmonary congestion during exercise.

\section{SUMMARY}

The pattern of respiration has been examined in 116 cases of rheumatic heart disease (55 with pure mitral stenosis and 61 with other valvular lesions) by the box-bag technique. Resting respiration is close to the normal pattern, although there is a slightly greater tidal volume than that found in control cases.

The vital capacity and expiratory reserve are considerably reduced. The decrease of vital capacity shows no clear correlation with disability, or with pulmonary arterial and pulmonary capillary pressures.

With exercise, the ventilation increases more than in normal subjects, and is mechanically less efficient. There is an abnormal increase of respiratory rate, and this forms a useful means of assessing pulmonary congestion.

The symptom of dyspnœa seems related primarily to the reduction of vital capacity, with some contribution from a decreased respiratory efficiency, and laboratory assessment of this symptom should therefore take account of both of these factors.

\section{REFERENCES}

Baker, C., Brock, R. C., Campbell, M., and Wood, P. (1952). Brit. med. J., 1, 1043.

Basch, S. (1891). Quoted by Halmagyi (1954).

Bülbring, E., and Whitteridge, D. (1945). J. Physiol., 103, 477.

Campbell, J. M. H., Hunt, G. H., and Poulton, E. P. (1923). J. Path. Bact., 26, 234.

, and Sale, F. J. (1927). Arch. intern. Med., 40, 237.

Cannon, E. F., Lucia, S. P., and Benson, E. H. (1939). Proc. Soc. exp. Biol. Med., $42,237$. 
Christie, R. V., and Meakins, J. C. (1934). J. Clin. Invest., 13, 323. (1953). Proc. Roy. Soc. Med., 46, 381.

Cournand, A., and Richards, D. W. (1941). Amer. Rev. Tuberculosis, 44, 123.

Donald, K. W., and Christie, R. V. (1949). Clin. Sci., 8, 21.

Drinker, C. K., Peabody, F. W., and Blumgart, H. L. (1922). J. Exp. Med., 35, 77.

Fenn, W. O. (1951). Amer. Forces Tech. Rep., 6528, 156.

Gübner, R., Schnur, S., and Crawford, J. H. (1939). J. Clin. Invest., 18, 395.

Halmagyi, D. (1954). Ärtliche Fortbildung. (Berlin), 48, 325.

Holling, H. E., and Venner, A. (1956). Brit. Heart J., 18, 113.

-, MacDonald, I., O'Halloren, J. A., and Venner, A. (1955). In preparation. and Zak, G. (1950). Brit. Heart J., 12, 153.

Lewis, B. M., Gorlin, R., Houssay, H. E. J., Haynes, F. W., and Dexter, L. (1952). Amer. Heart J., 43, 2.

Mack, I., Grossman, M., and Katz, L. N. (1947). Fed. Proc., 6, 161.

Nahas, G. G. (1951). Science, 113, 723.

Peabody, F. W., and Wentworth, J. A. (1917). Arch. intern. Med., 20, 443.

Richards, D. J. B., Whitfield, A. G. W., Arnott, W. M., and Waterhouse, J. A. H. (1951). Brit. Heart J., $13,380$.

Shephard, R. J. (1954). Ph.D. Thesis, University of London. (1955a). Brit. Heart J., 17, 153. $(1955 b)$. Thorax, 10, 258 .

Stocks, J. P. P., and Kennedy, M. C. S. (1953). Lancet, 2, 5.

Tarr, L., Oppenheimer, B. S., and Sager, R. V. (1933). Amer. Heart J., 8, 766.

Wade, O. L., Bishop, J. M., and Donald, K. W. (1954). Clin. Sci., 13, 511. 